\title{
Does large-sized cities' urbanisation predominantly degrade environmental resources in China? Relationships between urbanisation and resources in Changjiang Delta Region
}

\section{Citation}

Kim, Saehoon, and Peter G. Rowe. "Does large-sized cities' urbanisation predominantly degrade environmental resources in China? Relationships between urbanisation and resources in the Changjiang Delta Region." International Journal of Sustainable Development \& World Ecology 19, no. 4 (2012): 321-329.

\section{Published Version}

doi:10.1080/13504509.2011.647108

\section{Permanent link}

http://nrs.harvard.edu/urn-3:HUL.InstRepos:10056564

\section{Terms of Use}

This article was downloaded from Harvard University's DASH repository, and is made available under the terms and conditions applicable to Open Access Policy Articles, as set forth at http:// nrs.harvard.edu/urn-3:HUL.InstRepos:dash.current.terms-of-use\#OAP

\section{Share Your Story}

The Harvard community has made this article openly available.

Please share how this access benefits you. Submit a story. 
Does large-sized cities' urbanization predominantly degrade environmental resources in China? Relationships between urbanization and resources in the Changjiang Delta Region

Saehoon $\operatorname{Kim}^{\mathrm{a}^{*}}$ and Peter G. Rowe ${ }^{\mathrm{b}}$

${ }^{a}$ Department of Urban Planning and Design, Graduate School of Design, Harvard University, Cambridge, $M A$

48 Quincy Street, Gund Hall, Room 325, Graduate School of Design, Harvard University, Cambridge, MA 02138, USA

Phone: 1-617-999-9923 / Fax: 617-495-0446 / Email: skim5@gsd.harvard.edu

${ }^{b}$ Department of Urban Planning and Design, Graduate School of Design, Harvard University, Cambridge, $M A$

48 Quincy Street, Gund Hall, Room 325, Graduate School of Design, Harvard University, Cambridge, MA 02138, USA

Phone: 1-617-495-4237 / Fax: 617-495-0446 / Email: prowe@gsd.harvard.edu

*Corresponding author: Saehoon Kim

Journal name: International Journal of Sustainable Development \& World Ecology 


\title{
Does large-sized cities' urbanization predominantly degrade environmental resources in China? Relationships between urbanization and resources in the Changjiang Delta Region
}

\author{
An outward expansion of urban lands in developing nations is often associated with a \\ substantial loss of environmental resources such as forests, wetlands, freshwater, and \\ cash crop fields. Yet, determining how different aspects of urbanization-such as city \\ population size and the spread pattern of built-up lands-contribute to the cumulative \\ loss of resources remains controversial. In this study, data sets were constructed \\ describing changes to land cover across 65,200 grid cells at $1 \mathrm{~km}^{2}$ of spatial resolution \\ for China's Changjiang Delta Region over the past sixty years. The results showed that \\ the region lost $12.2 \%$ of total resource sites. The distribution of resource degradation \\ showed a highly dispersed pattern and was not confined to a few intense areas \\ associated with large-sized cities. No empirical evidence was found that city population \\ size alone accurately predicts the distribution of resource loss. Very large cities $(\mathrm{N}=4)$ \\ contributed 35\% of the total loss, demonstrating impacts similar to those of much more \\ scattered towns $(\mathrm{N}=230)$. An urban expansion of large-sized cities may truly lead to an \\ extensive resource loss. But a set of non-linear mechanisms, such as the diminishing \\ effects of per-unit area urban spread on resources and interactions between urban \\ patterns and the size of urban spread, also can play a significant role in downsizing the \\ negative effects of large cities on resource sites. Thus, effective urban policies should \\ carefully weigh the cumulative urban-spread mechanisms of both the large and small- \\ sized cities responsible for a spatially-dispersed degradation of environmental \\ resources.
}

Keywords: environmental resources; urbanization; land-cover change; urban patterns; Changjiang Delta Region; China

\section{Introduction}

Coastal regions' fertile lands produce some $77 \%$ of global ecosystem services, such as food, water, climate control, and disaster prevention (Burke et al. 2001; Martínez et al. 2007). These regions also provide different-sized urban settlement for more than a third of the world's population and within only 4\% of the Earth's total surface (UNEP 2006; World Bank 2010). 
Yet, in the face of large-scale urbanization, an outward expansion of urban lands is causing a substantial transformation of urban-rural fringe lands, especially in the coastal areas of predominantly rural nations like China. Although major Chinese cities took the first steps to protect land and water resources beginning with Shanghai in the 1980s (IOSG 2010), this does not indicate that all the remaining important sites have been safeguarded (Zhao et al. 2006; Lin et al. 2010) and places a priority on investigating spatial and temporal variation in the cumulative resource loss generated by the expansion of urban lands. In short, several important questions remain. Is the rapid expansion of a few major cities predominantly responsible for a region's loss of resources, or is resource loss a fundamentally dispersed process that involves a number of different-sized cities? What aspects of urbanization, such as city population size or certain quantitative components of urban spread, better explain the degradation? In approaching these questions, the impact of different-sized cities on resources was divided into two parts: (i) increases in urban land, or a 'size factor', and (ii) resource loss per-unit area of urban land, or an 'efficiency factor’ of urban spread.

The benefits of environmental resources near cities abound. For instance, food, water, wood, minerals, and by-products of urbanization, such as waste and pollutants, can be transported to and from cities at reduced time and cost. Flood control, water purification, climate regulation, and maintenance of species habitats can more directly benefit human settlements. Also, recreational amenities and cultural heritage sites located in proximity to cities tend to attract large crowds, generating measurable and non-measurable economic value (Forman 1995; MEA 2005; Li et al. 2010). In this study there was a focus on forestlands, freshwater sites, wetlands, and cash crop fields located in China's lower Changjiang Delta Region. These resources were clearly discernible from classified remote-sensed imagery and were available from multiple sources of spatial data and from planning documents. All four resources occupied a significant portion of the study area (> 5\%, respectively), and 
corresponded to international and local land-cover standards (Liu et al. 2002; Lillesand et al. 2004). The four land types are referred to as “environmental resources,” defined as natural or human-modified land capital that produce valuable ecological services and environmental benefits (Dasgupta and Mäler 1995; Forman 2008).

The Changjiang Delta Region covers $65,200 \mathrm{~km}^{2}$ of terrestrial land and 10,200 $\mathrm{km}^{2}$ of freshwater bodies, located at $30^{\circ} 06^{\prime}-32^{\circ} 30^{\prime} \mathrm{N}$ and $118^{\circ} 39^{\prime}-121^{\circ} 58^{\prime} \mathrm{E}$ and with the highest elevation at 1,587 m above sea level (Figure 1). It includes 16 regional-level cities, 30 countylevel cities and 1,730 towns, with a total of some 62 million household-registered inhabitants in 2005. The region is comprised of an alluvial flat land located in a transitional zone between the Changjiang (Yangtze River) and the East China Sea, large water bodies such as Taihu and Gehu Lakes, as well as mountainous regions in the Zhejiang and Anhui provinces. Some 7,000 years ago, the deltaic land grew gradually seaward due to the accumulation of sediment trapped by the extensive flood plains, forming Shanghai's eastern boundary in the early twentieth century (Sit 1998). Taihu Lake, China’s third-largest freshwater body, is located at the centre of the region, with some $55.3 \%$ of its watershed made up of lowlands less than $3 \mathrm{~m}$ above sea level (Sun \& Mao 2008). Urban built-up land has expanded remarkably in the region, from approximately $804 \mathrm{~km}^{2}$ in the 1950s to 6,726 $\mathrm{km}^{2}$ in 2010. Between 1979 and 2000, the rate of urban land expansion was fairly high at about $4.7 \%$ per year, which was faster than the annual urban population growth rate of 3.5\% between 1985 and 2005 (author's calculation for 16 regional-level cities in the region; CCSY).

This paper attempts to make methodological advancements in the findings of previous studies (e.g. Wang et al. 2008), which were limited largely to the non-spatial, cross-sectional estimation of the delta region's resource sites and its ecosystem service values. The spatial aspects of land-cover changes since 1950 were investigated by locating fine-scaled vector data points on a consistent coordinate system. Also included was the eastern part of Anhui 
Province, representing $15.7 \%$ of the region's total terrestrial lands, which has an extensive forest zone that was selected as one of China's 33 priority conservation areas (Xie 2009). A regression method using stratified sampling was applied to determine influential urban aspects linked to resource degradation. However, non-physical effects of urbanization, such as air pollution or climatic change, were not included.

\section{Methods}

Time-series land-cover data sets were created for the years of 1950, 1979, 1990, 2000, and 2010 based on multi-band remote-sensed images, high-resolution aerial photographs, and digitized historic and land-use planning maps. To identify seven standardized land-cover classes, including urban built-up land, agricultural land, rangeland, forest, water bodies, wetland, and barren land (Anderson et al. 1976), on-screen visual interpretation was carried out using Landsat Orthorectified Multispectral Scanner (MSS, 57 meter resolution, recorded in August 1979), Thematic Mapper (TM, 30 meter resolution, recorded in August 1989), and Enhanced Thematic Mapper Plus (ETM+, 30 meter resolution, recorded in July 2001) acquired from the U.S. Geological Survey (USGS) Earth Resources Observation and Science Center. Before analysis, these images were geometrically rectified, re-projected, and resampled using ERDAS Imagine with a 100 meter resolution. A supervised classification of the maps was conducted using the maximum likelihood classifier in Multispec to produce consistent land-cover information. To complement partially missing information, over 200 spatially referenced historic maps and aerial photographs (circa 1963 and 2010) were compiled, as well as some 100 urban planning reference maps published by local municipalities. Consultations were also held with four Chinese institutions in May and June of 2011, including at Fudan University Historical Geography Institute, Tongji University College of Architecture and Urban Planning, Suzhou Bureau of Construction, and with the 
Segacn Real Estate Group in Changzhou. All data sets were georeferenced in ArcGIS to the Xian 1980 GK Zone 19 coordinate system.

The distribution of environmental resources_-forests, freshwater sites, cash crop fields, and wetlands - and the location of urban spread were mapped using the established database. The region's land was subdivided into $1 \mathrm{~km}^{2}$ grid cells and a dominant land-cover type within each cell was recorded. The size of grid cells was chosen based on the coarse resolution of historic maps that were at best accurate within an approximately $0.5 \mathrm{~km}$ distance. Areas of forests were predominantly occupied by secondary evergreen-broadleaf and mixed deciduous forests (Xu et al. 2010). Freshwater sites included lakes (>1 $\mathrm{km}^{2}$ ), rivers (> $100 \mathrm{~m}$ in width), aquaculture sites $\left(>1 \mathrm{~km}^{2}\right)$, and the vegetated buffer $(\mathrm{d}=1 \mathrm{~km} \sim 5 \mathrm{~km})$ along the water bodies. Water bodies that were not open to any type of hydrological change were excluded. The vegetated buffer distances were chosen based on the slope of land and soil texture $(d=1$ $\mathrm{km}$ if slope $<2^{\circ}$ and sandy soil; $\mathrm{d}=5 \mathrm{~km}$ if slope $>5^{\circ}$ and clay soil), according to the landscape ecology theory that a vegetated buffer prevents pollutants from entering streams and improves the in-stream processing of pollutants (Allan et al. 1997; Wang et al. 2001; Allan 2004). Cash crop fields included cotton, oil crops, linen, medicinal plants, and tobacco fields, which were digitized from GJDT (1993). Lastly, to identify the areas of wetlands, satellite maps, aerial photos, and recent GIS vector data of the 2000 Wetland Map of China created by Gong et al. (2010) were integrated. There was a wide variability in the accuracy of the region's spatial data, given the scarcity of land-cover information before the 1980s and the difference in the resolution of the original references. In some instances, reference maps were used to supplement remote-sensed images, or land-cover information in 1950 was rounded based on 1970s’ data sets. In other cases, data accurate enough to rank as sound for the purpose of working estimates at a 100 m resolution (maps after 1979) and $1 \mathrm{~km}$ resolution (maps before 1979) were found. Once all data sets were vectorized, the locations of resource 
sites with urban spread sites were overlapped to illustrate cumulative resource loss by urban spread. To qualify as a resource site converted to urban land, the proportion of urban land within the cell must exceed all other types of land cover that used to dominate the cell.

The spatial correlation between city size and resource loss was tested by using both a scaling-function formula suggested by Bettencourt et al. (2007) and a buffer-graph method. First, the scaling-function method uses population $\left(N_{t}\right)$ as a measure of city size (at time $t$ ) that explains various urban indicators $\left(Y_{t}\right)$, expressed as $Y_{t}=Y_{0} N_{t}^{\beta}$. In our study, $Y_{t}$ was defined as a log of the area of resources lost to urban spread within a sample boundary. Second, the buffer-graph method calculates the percentage of resource areas lost to urban spread within multiple buffer rings drawn from city and town centres. The radii of buffers were incrementally increased by 500 m intervals until the buffer areas reached $100 \%$ of the region's total lands. The four largest cities in the region $(\mathrm{N}=4$ : Shanghai, Wuxi, Nanjing, and Hangzhou), together with mid-sized cities ( $N=12$ : cities with population between 200,000500,000 in 2000), and much smaller towns ( $N=230$ : towns with population > 50,000 in 2000) were tested in this manner.

Once a general relationship between city size and resource loss was investigated, stratified sampling of 94 sub-regions was conducted for multiple regression analyses. Two components of city-size effects-increases in urban spread (size factor) and pattern metrics of urban spread (efficiency factor)—were the main variables of interest related to the region’s resource loss, controlling for other variables such as soil groups. Stratified sampling is known to reduce the variance of its estimation when analyzing spatially non-homogeneous phenomena (Richards et al. 2000; Achard et al. 2002). Thus, sampling boundaries were drawn based on three criteria: (i) areas with a population density $>=1000$ people per $\mathrm{km}^{2}$, measured based on Population Grid Data 2000 (grid size = 1 km by 1 km); (ii) areas surrounded by major geographic barriers like mountain ridges or large water bodies; and if delineating a 
boundary between two cities was difficult owing to the agglomeration of dense urban settlements, (iii) their relative population sizes were used to define their boundaries. Different population density criteria were tested for comparison, as the model outcomes could be sensitive to the specifications of the sample boundaries. Any density substantially larger than 1000 people per $\mathrm{km}^{2}$ included only highly urbanized areas near urban districts; sample subregions with a density lower than 1000 people per $\mathrm{km}^{2}$ covered too much rural land, which substantially limited the variation in resource loss ( $<<10 \%)$. Consequently, a 1000 people per $\mathrm{km}^{2}$ definition was selected because it helped to include densely populated urban districts, adjacent urban settlements with heterogeneous land-cover patterns, and extended rural sites directly linked to dense urban settlements. This avoided the problem of 'over-bounded' or ‘under-bounded’ sample boundaries. This density criterion was higher than Wolman’s comparable study (2005), since Chinese urban regions are far denser than the metropolitan regions of the United States. Samples less than $10 \mathrm{~km}$ from another sample boundary or without any significant land-cover changes were excluded. Using the selected samples, the following variables were measured: (i) the average percentage of resource sites lost to urban spread (dependent variable), (ii) the natural logarithm of total population in 2000 acquired from the University of Michigan China Data Center (2007) and total population growth ratio between 1997 and 2005 as a proxy for pressure on resources, (iii) increases in the number of cells with urban spread between 1950 and 2010, (iv) Moran’s coefficient (Moran’s I) for measuring degrees of clustering of urban spread, (v) urban characteristics such as the length of expressways, distances to major cities, the number of nearby towns, density of industrial enterprises, and per-capita GDP in 2010, and (vi) multiple geophysical variables such as soil groups (clay/silt/sand), average land slopes, the presence of timber and metal mining sites, land subsidence and flood. Tsai (2005) tested the validity of Moran's I for measuring the relative clustering (or scattering) of urban forms, showing that the index could distinguish 
compact urban patterns from scattered forms. While Galster et al. (2001) proposed what is probably the most comprehensive sprawl index, it was not applicable to this study because its calculation was based on residential forms and the standardized parameter of the index did not offer direct interpretation. For Moran’s I, fixed distance bands of 3km were used where the zscore of spatial clustering peaked. Stepwise multiple regression analyses were conducted with the backward elimination method (maximum P-value to retain the variables $=0.05$ ). When all variables were tested for multicollinearity, urban spread and Moran’s I showed a correlation. However, they were not excluded in order to be inclusive of interaction effects of major variables on resource.

\section{Results}

\section{A highly dispersed pattern of environmental resource loss}

The region lost some $12.2 \%$ of total environmental resource sites between 1950 and 2010 (the total number of resource cells decreased from 45,817 to 40,211 as shown in Table 1). Forests decreased by $13.6 \%$, freshwater sites by $13.3 \%$, cash crop fields by $9.8 \%$, and wetlands by 7.9\% (Figure 1). [Figure 1 near here] The cumulative losses showed a highly dispersed pattern across the region, rather than being confined to a few major areas of intensity near large-sized cities. The buffer-graph method showed that only 35\% of the region's total losses have taken place within $30 \mathrm{~km}$ of the four largest cities, or $15 \%$ of the total land surface. The remaining portion, or $65 \%$ of the region's resource losses, was associated with the urban spread located away from the immediate fringes of very large cities. The same proportion of land near much smaller towns $(\mathrm{N}=230)$ accounted for some $30 \%$ of the total resource loss, demonstrating very similar degradation effects between large cities and small towns. [Table 1 near here] Sensitivity analysis was conducted to test whether the dispersion of resource loss 
was a result of the definition of the buffer area around cities and towns. However, even when the area definition of the buffer rings changed, the extent of the percentage of resource areas lost to urban spread between very large cities and small towns remained similar (Figure 2). For example, redefining $30 \%$ of the total land surface as buffer areas made only a small percentage of difference between the four largest cities (51\%) and small towns (45\%). Thus, it can be safely inferred that a few large cities did not consume a disproportionately large amount of resource sites in the region. By contrast, effects of mid-sized cities' urban spread were smaller than the other groups: $15 \%$ of the total land near mid-sized cities $(\mathrm{N}=12)$ explained only $21 \%$ of the total resource losses. [Figure 2 near here]

There was a low spatial association among the losses of different resources insofar as a high ratio of one type of loss was not always matched by the high ratio of other types of resources. Pearson's correlation analyses revealed that the pairwise correlation coefficients of four resources were fairly small $(<0.3)$, with the exception of the relationship between cash crops and freshwater sites. The cities of Shanghai, Nanjing, Suzhou, and Xuancheng presented considerably uneven proportions of losses. For example, urban spread in Shanghai comprised $27.1 \%$ of the region's total of lost cash crop fields, whereas its forest loss comprised only $0.4 \%$; Nanjing's forest loss comprised 30.6\%, while wetland loss comprised 5.5\%; Xuancheng's forest loss comprised 9.2\%, while freshwater sites loss comprised only $0.1 \%$. By contrast, the Changzhou-Wuxi-Zhenjiang region showed a relatively even proportion of loss, including $21 \%$ of total lost forests, $24.5 \%$ of wetlands, $21.2 \%$ of freshwater sites, and 13.9\% of cash crop fields. The Huzhou and Jiaxing regions also showed a similar congruence ratio of $15.1 \%, 12.8 \%, 10.2 \%$, and $9.3 \%$, respectively, across the same resources. 


\section{A non-linear relationship between city size and resource degradation}

City size showed a weak, statistically insignificant correlation with resource loss. The scalingfunction test of city size showed that the log of resource loss $(Y)$ was positively associated with the log of city size $(N)$, but the predictive capability of city size was fairly small (adjusted $\mathrm{R}^{2}=0.30, \beta=0.535 \pm 0.201, \mathrm{~N}=94$ ). A scaling exponent value of this formula, or $\beta$, was far smaller than 1, indicating that certain mechanism of economies of scale shows up relative to the loss of environmental resources as the size of a city increases. When multiple variables were controlled for in the stepwise regression, city size was eliminated as nonsignificant. On the other hand, increases in urban spread and its degrees of spatial clustering, measured by Moran’s I, were retained as significant when soil types and the rate of total population growth were held constant (Table 2). These results showed that city size may be an underlying but not singularly significant cause of land-cover change associated with resource loss in the region. A probable interpretation of this result is that the multiplication of a 'size factor' and an 'efficiency factor' explains some unanticipated outcome of city size effects on resource loss. [Table 2 near here]

The log of increases in the urban spread, or a size factor, was significantly associated with resource loss. The best-fit equation was:

$$
Y=-1.9+4.8 \log X\left(\text { adjusted } \mathrm{R}^{2}=0.34\right)
$$

where $Y$ is the average percentage of loss of resource sites and $X$ is the number of increased urban spread cells between 1950 and 2010, when one cell unit is equivalent to a $1 \mathrm{~km}^{2}$ resolution. The level-log relationship has an intuitively clear meaning, i.e., larger urban spread consumes increased resources, but the effects of additional per-unit area urban lands decrease as city size increases. In other words, resource loss is a saturating function of urban spread because, in largely developed areas, an additional expansion of urban lands is more likely to 
be similar to existing urban forms. In the same vein, in small urban places, the progressive increases in urban lands should have far greater negative impacts on resources than in larger cities.

The Moran’s I value of urban spread patterns, or an efficiency factor, ranged from -0.4 (highly dispersed) to +0.6 (highly clustered). Its regression coefficient was positive, meaning that in general, more clustered urban patterns were associated with increased resource loss (P $<0.001)$. This outcome is counter-intuitive, since sprawl-like urban forms are frequently associated with increased land consumption (Johnson 2001). One likely explanation for the result here is that Moran’s I strongly interacts with urban spread, thus its effects vary widely depending on the magnitude of the spread. Pearson's correlation test supported this idea, showing a correlation coefficient that was fairly high at 0.47 , while multicollinearity in other variables was not significant (all other correlation coefficients were $<0.2$ ). Why then do urban patterns depend on the size of urban spread? In extensively built-up cities, developing new land far away from previously developed areas is often avoided, thus Moran's I is expected to increase, due to the benefits of sharing existing infrastructure, social service facilities, and the proximity between housing and places of employment. Thus, in general, increases in urban size result in more clustered urban patterns. However, this trend may be reversed, or Moran's I can be lowered in the process of urbanization, if continuous urban development is discouraged. For example, the presence of dense villages on the urban fringes or socially-valued resource lands can be resistant to urban development, since the estimated return of urban lands may not be obviously higher than the sum of current land productivity and total costs for development in the long run. This interactive relationship between size and pattern of urban spread leads to a skewed U-shape graph between Moran's I and resource loss per-unit area urban spread (Figure 3). The graph indicated that a highly dispersed urban pattern, as well as a highly-clustered pattern to some extent, is more associated with increased 
resource loss per-unit area of urban spread than moderately compact patterns. [Figure 3 near here] Therefore, despite a relatively small-sized urban spread, a city may have amplified negative effects on resources if its spatial pattern is associated with both ends of the graph. Shizhuangzhen in Rugao, for example, shows a highly dispersed spread pattern (Moran’s I = 0.19), which is associated with its fairly high resource loss of $30.9 \%$. Similarly, the clustered urban spread of Haining (Moran’s I = 0.41), a small-sized city with population 64,000 in 2000, has affected the inner-city resource sites (total resource loss $=27.7 \%$ ) such as the severe pollution of Xiashizhen groundwater sources (Class V in 2005) and the Dongshan forest largely decreased in size by newly developed industrial buildings (HSDF 2006).

\section{Complicated forces behind land-cover change}

Urban spread, despite its statistical significance, has led to varying degrees of resource degradation when individual resource was examined separately. For example, the loss of forests and wetlands had no significant relationship with the relative increases in urban lands, as measured by the ratio of urban lands in 2010 to the year of 1950 . On the other hand, the loss of cash crop and freshwater sites was a strongly positive function of urban spread. This inconsistency among resources is due partly to the uneven distribution of resources and human intervention in community-specific land cover. For example, cash crop fields were located adjacent to mid- to large-sized cities in the eastern part of the region, as well as in rural areas away from cities to the west of Taihu Lake. This bifurcated distribution led to a relatively high clustering of cash crop losses near Shanghai and Suzhou. For example, some $38.5 \%$ of Shanghai's total sown areas, including grain and cash crop fields, were eliminated between 1990 and 2008 (Editorial Committee of Expo Shanghai Atlas 2010). Yet, the amount of net loss in the region was not surprisingly high (9.8\%), since it was offset by newly cultivated cash crop fields in the Jiangsu and Zhejiang Provinces. The ratio of cash crop to 
other types of sown areas, for example, increased from 13\% to 16\% in Jiangsu and from 9.5\% to 11.5\% in Zhejiang Province between 1998 and 2002 (Yuan et al. 2005). Lost wetlands and freshwater sites were scattered to the east, north, and south of Taihu Lake, and along the coasts of the Changjiang and the East China Sea. The annual rate of wetland loss was estimated at only $0.14 \%$ over the last sixty years. Between 1990 and 2000, the rate was the highest at $0.6 \%$. Interestingly, the region's net wetland loss was far slower than the national average of $1.5 \%$ (Gong et al. 2010), owing to the natural growth of marshlands, estuaries, and constructed wetlands in the study area. Also, the region was not as strongly affected by macro-climatic fluctuation like temperature change and drought as other areas like China's Northern plain (Qian and Zhu 2001).

Environmental policies designed to protect natural lands may also have affected the non-linear relationship between urban spread and resource loss. An aggregate area of 13,525 $\mathrm{km}^{2}$, or $3.8 \%$ of the total surface of the region's four provinces, was protected as nature reserves as of 2009 (MEP 2010). Shanghai has the highest proportion of these, with $14.3 \%$ of the total land surface protected. Forests and wetlands are the major land types within these reserves; for example, 84\% of Jiangsu's nature reserves are comprised of either wetlands or forests (26 out of 31 sites; Jiangsu Province 2009). In effect, the urbanization process may have a reduced or indirect impact on the protected lands of some forests or wetlands.

\section{Discussion}

In this analysis, resource degradation in the Changjiang Delta Region does not appear to be confined to the urban fringes of large-sized cities. Further, city size alone does not explain the distribution of resource loss. The extensive urban spread of large cities may truly lead to a substantial loss of resources. But a set of non-linearly performing factors, such as the 
diminishing effects of per-unit area urban spread on resources, interactions with its spatial patterns, and high variations amongst different resource types linked to the interventionist regime, play a significant role in downsizing the effects of large-sized cities on resource degradation. More conceptually, the effects of population growth on resources, and the associated spread of urban lands, are offset by the increased efficiency factor during the urbanization process. This non-linear mechanism of urban growth may explain why city size is not proportionally associated with increased resource degradation, despite the sustained regularity of city size on a broad set of urban indicators like wealth creation, employment, housing provision, and energy uses (Bettencourt et al. 2007). The more centralized expansion of larger cities may incorporate both inner-city redevelopment opportunities and new development away from important resource sites. On the other hand, urban spread in smaller cities may lead to an increased susceptibility of resources to disturbances due to dispersed or polycentric patterns of expansion. Also, small cities may have limited institutional capacities, widespread poverty, and low functional specialization for maintaining the environmental quality, leading to immature coping when faced with the rapid degradation of common-pool resources.

Following on from this analysis, it is clear that the simultaneous growth of small and large cities poses challenges to the conservation efforts of local governments. A singular approach of protecting only hotspots of environmental threats is difficult to achieve in a region where different-sized urban settlements are affecting the land-cover patterns. Additionally, policies designed to minimize the development of urban lands may have the unintended effect of suppressing reasonable supplies of developable lands in well-managed cities, despite a policy's practical role in saving resource lands. This may in turn lead to the depletion of productive lands by motivating the rapid spread of much smaller cities and villages with highly duplicative and land-consumptive urban patterns. No causal relationship 
should be inferred, but the region's resource loss and its spatial dispersion seems to be highly attributed to the diminished efficiency factor of urban land use in small cities and towns. In short, land-use control in an urbanizing region is necessary but not sufficient to ensure the conservation of the most valuable resource lands located between interconnected cities.

More from a historical perspective, during the booming period of urbanization in China since 1978, on-ground environmental management efforts hardly achieved their intended goals and were overshadowed by other urgent goals of economic development and poverty reduction. The growth of small-sized cities and towns was promoted as a national policy at China’s 1980 National Conference on Urban Planning. Small cities and towns came to be vigorously linked with larger cities to export industrial productions to larger markets, to channel surplus population into rural industries, and to transfer basic social services to underdeveloped villages (Kwok 1982). Simultaneously, larger cities were designated as growth centres under urban reform, although overly concentrated urban growth was curtailed up to a point (Rowe 2005). A series of governmental policy interventions, including the first National Land Survey (1984-1996), the Land Administrative Law with several amendments (1986), and the designation of nature reserves, were met with scepticism because of their lack of capital investment, the conflicts with localized economic gains, and the vague definition of preservation goals. (Lin and Ho 2003; Liu et al. 2003). More recently, at least six key forestry programs were initiated beginning in the late 1990s. However, the central government’s total investment in the programs was less than $0.2 \%$ of the national GDP in 2005, which was very minor compared to the nation's enormous environmental damage (Wang et al. 2008; NBS 2009).

Yet, the region's priority on urbanization and economic growth scarcely resulted in an unmitigated destruction of productive resource lands, despite some cases of large-scale arable land loss. China’s institutional players-from rural collectives to municipal governments- 
appear to have valued productive land resources for very practical reasons. In Dongshanzhen of Suzhou, for example, cultivating aquaculture products (e.g. crabs) and cash crops (e.g. waxberry and pipa) generated the dominant sources of rural income, which in turn stabilized the livelihood of rural villages and generated high tax revenues from increased agricultural outputs. Thus these lands were expanded up to $36.6 \%$ of the town's total land, whereas the lowland of forests was selectively converted into urban settlements for the booming tourism industry (Dongshanzhen Government 2007; author’s interview with Professor Rongsan Ruan). Additionally, land-cover conversions from resource sites to urban lands occurred in a very selective process and were generally under the control of local governments and collectives. During the mid 1980s, local governments were empowered with fairly strong control over land development, such as preparing annual land-use plans and issuing licenses for land conversions under the central quota-allocation system. At a metropolitan scale, Shanghai was the first Chinese city that protected its drinking water sources under the Regulations on the Water Source Protection of the Upper Reach of Huangpu River of 1985. Shanghai's government constructed sewage pipes, relocated enterprises that did not meet pollution standards, closed 173 livestock farms, and reforested some $44 \mathrm{~km}^{2}$ of land along the river (IOSG 2010; Krantzberg et al. 2010). Due to these efforts, there were minimal land developments along the $5 \mathrm{~km}$ buffer of the river's upper reach, with an annual rate of urban spread $<2 \%$, which was far slower than the city’s overall rate of 3.1\% between 1979 and 2010.

This trend of rising administrative power of cities, collective demands for wellmaintained environmental resources, and continued land consumption by urban households will pose both challenges and opportunities in the Changjiang Delta Region. Rigid regulatory controls on urban development or a complete freeze on the transfer of land-use rights may not be realistic, due to the region's economic contribution to the production of $19 \%$ of the 
national GDP and 29\% of the nation's export commodity value (Rowe 2011). A large portion of resource lands will be outbid by land developers, since the economic value per area of urban land far exceeds the value of natural resource lands. Also, the region is already one of the areas with the highest conservation costs in light of rehabilitating its cumulative damage and relocating existing villagers living in dense rural settlements, along with the Northeast Plain, the Pearl River Delta, and the Sichuan Province (Xie 2009). It is true that the rate of China's urbanization will probably stabilize in the next few decades, bottom-up demands for environmental remediation will come into play, and the decommissioning of aging infrastructure will be carried out for both economic gain and ecological restoration. However, the region's environmental threats and instances of scarcity are in an expanding rather than contracting phase. Per-capita arable land was no more than 0.04 ha/person in 2005, and rapidly shrinking. Indeed it was less than half of the national average of 0.11 ha/person, and less than one fourth of the world average of 0.23 ha/person, or of the United States' average of 0.62 ha/person (World Bank 2004). More broadly, Asia’s consumption of resources has been soaring over the last five decades. In 1961, 55\% of the world's population lived in Asia, consuming $22 \%$ of world's fertilizer, $13 \%$ of world's meat, and $27 \%$ of world's domestic materials, including construction materials. In 2007, Asia’s population percentage increased only slightly to $60 \%$, while resource use increased sharply to 55\% (fertilizer), $43 \%$ (meat), and 54\% (domestic materials), respectively (Galloway et al. 2008; FAO 2009; Schandl and West 2010). Thus, the multiplier effects of increased resource consumption, including percapita land and water, are likely to reshape both the regional and global environment.

\section{Acknowledgements}

This research was supported by the East-West Cultural Development Center and Foundation and the Association for Asian Studies. We thank Paul Cote, Richard Forman, and Niall Kirkwood for their 
comments. In China, Li Hou, Yangfang Hou, Youngwoo Park, Wenhui Shan, Songdi Wu, Yue Wu, Hyuckjin Yoon, Abraham Zamcheck, and Xiaohong Zhang provided important local knowledge to the authors. Our research is indebted to the collaborative database building by Nan Cao, Li Hou, Sanghoon Jung, Har Ye Kan, Jon Kher Kaw, Nick Smith, and Jihoon Song. 
References

Achard F, Eva HD, Stibig HJ, Mayaux P, Gallego J, Richards T, Malingreau JP. 2002. Determination of deforestation rates of the world's humid tropical forests. Science. 297(5583):999-1002.

Allan JD, Erickson DL, Fay J. 1997. The influence of catchment land use on stream integrity across multiple spatial scales. Freshwater Biology. 37(1):149-161.

Allan JD. 2004. Landscapes and riverscapes: the influence of land use on stream ecosystems. Annual Review of Ecology, Evolution, and Systematics. 35:257-284.

Anderson JR, Hardy E, Roach J, Witmer R. 1976. A land use and land cover classification system for use with remote sensor data. US Geological Survey Professional Paper. 964:1-36.

Bettencourt LMA, Lobo J, Helbing D, Kühnert C, West GB. 2007. Growth, innovation, scaling, and the pace of life in cities. Proceedings of the National Academy of Sciences. 104(17):7301-7306.

Burke L, Kura Y, Kassem K, Revenga C, Spalding M, McAllister D. 2001. Pilot analysis of global ecosystems: coastal ecosystems. Washington (DC): World Resources Institute.

[CCSY] China City Statistical Yearbooks. 1986, 1991, 1996, 2001, and 2006. Beijing (China): China Statistics Press.

Dasgupta P, Mäler K-G. 1995. Poverty, institutions, and the environmental resource-base. In: Handbook of development economics. New York: Elsevier. p. 2371-2463.

Dongshanzhen Government. 2007. Business invitation manual of Dongshanzhen Wuzhong district. Suzhou (China): People's Government of Dongshanzhen.

Editorial Committee of EXPO Shanghai Atlas. 2010. Shanghai atlas. Beijing (China): Sinomaps. Chinese.

[FAO] Food and Agriculture Organization of the United Nations. 2009. FAO statistical databases. Available from: http://faostat.fao.org

Forman RTT. 1995. Land mosaics: the ecology of landscapes and regions. Cambridge (UK): Cambridge University Press.

Forman RTT. 2008. Urban regions: ecology and planning beyond the city. Cambridge (UK): Cambridge University Press.

Galloway JN, Dentener FJ, Marmer E, Cai Z, Abrol YP, Dadhwal V, Vel Murugan A. 2008. The environmental reach of Asia. Annual Review of Environment and Resources. 33:461-481. 
Galster G, Hanson R, Ratcliffe M, Wolman H, Coleman S, Freihage J. 2001. Wrestling sprawl to the ground: defining and measuring an elusive concept. Housing Policy Debate. 12(4):681-717.

[GJDT] Guo jia di tu ji bian zuan wei yuan hui. 1993. Zhonghua renmin gongheguo guo jia jing ji di tu ji [China national economic atlas]. 1st ed. Beijing (China): China Cartographic Publishing House. Chinese.

Gong P, Niu ZG, Cheng X, Zhao KY, Zhou DM, Guo JH, Liang L, Wang XF, Li DD, Huang HB. 2010. China’s wetland change (1990-2000) determined by remote sensing. Science China Earth Sciences. 53(7):1036-1042.

[HSDF] Haining Shi di fang zhi bian zuan wei yuan hui bian. 2006. Haining nian jian [Haining yearbook]. Beijing (China): Zhong hua shu ju. Chinese.

[IOSG] Information Office of Shanghai Government [Internet]. 2010 Jan 22. Shanghai (China): Shanghai Municipal Government. Available from: http://www.shio.gov.cn/ Jiangsu Province. 2009. List of nature reserves in Jiangsu Province. Nanjing (China): Jiangsu Province Environmental Protection Department.

Johnson MP. 2001. Environmental impacts of urban sprawl: a survey of the literature and proposed research agenda. Environment and Planning A. 33(4):717-735.

Krantzberg G, Tanik A, do Carmo JSA, Indarto A, Ekda A. 2010. Advances in water quality control. New York: Scientific Research Publishing.

Kwok RYW. 1982. The role of small cities in Chinese urban development. International Journal of Urban and Regional Research. 6(4):549-565.

Li X, Gao L, Dai L, Zhang G, Zhuang X, Wang W, Zhao Q. 2010. Understanding the relationship among urbanisation, climate change and human health: a case study in Xiamen. International Journal of Sustainable Development \& World Ecology. 17(4):304-310.

Lillesand TM, Kiefer RW, Chipman JW. 2004. Remote sensing and image interpretation. 5th ed. New York: Wiley.

Lin GCS, Ho SPS. 2003. China's land resources and land-use change: insights from the 1996 land survey. Land Use Policy. 20(2):87-107.

Lin J, Li Y, Wang W, Cui S, Wei X. 2010. An eco-efficiency-based urban sustainability assessment method and its application. International Journal of Sustainable Development \& World Ecology. 17(4):356-361. 
Liu J, Mingliang L, Xiangzheng D, Dafang Z, Zengxiang Z, Di L. 2002. The land use and land cover change database and its relative studies in China. Journal of Geographical Sciences. 12(3):275-282.

Liu J, Ouyang Z, Pimm S, Raven P, Wang X, Miao H, Han N. 2003. Protecting China's biodiversity. Science. 300(5623):1240-1241.

Martínez ML, Intralawan A, Vázquez G, Pérez-Maqueo O, Sutton P, Landgrave R. 2007. The coasts of our world: ecological, economic and social importance. Ecological Economics. 63(2-3):254-272.

[MEA] Millennium Ecosystem Assessment. 2005. Ecosystems and human well-being: our human planet: summary for decision-makers. Washington (DC): Island Press.

[MEP] Ministry of Environmental Protection of the People's Republic of China. 2010. Statistics on national nature reserves 2009. Beijing (China): National Environmental Protection Bureau.

[NBS] National Bureau of Statistics of China. 2009. China yearly macro-economy statistics. Beijing (China): National Bureau of Statistics. Available from: http://chinadataonline.org/

Qian W, Zhu Y. 2001. Climate change in China from 1880 to 1998 and its impact on the environmental condition. Climatic Change. 50(4):419-444.

Richards T, Gallego J, Achard F. 2000. Sampling for forest cover change assessment at the pan-tropical scale. International Journal of Remote Sensing. 21(6):1473-1490.

Rowe PG. 2005. East Asia modern: shaping the contemporary city. London (UK): Reaktion.

Rowe PG. 2011. Urban formation in China since 1950 seen from afar. China City Planning Review. 20(1):6-14.

Schandl H, West J. 2010. Resource use and resource efficiency in the Asia-Pacific region. Global Environmental Change. 20(4):636-647.

Sherbinin AD, Carr D, Cassels S, Jiang L. 2007. Population and environment. Annual Review of Environment and Resources. 32:345-373.

Sit VFS. 1998. Geography and natural resources. In: Shanghai and the Yangtze Delta: a city reborn. Hong Kong (China): Oxford University Press. p. 74-118.

Sun S, Mao R. 2008. An introduction to Lake Taihu. In: Lake Taihu, China: dynamics and environmental change. London (UK): Springer. p. 1-68.

Tsai Y. 2005. Quantifying urban form: compactness versus sprawl. Urban Studies. 42(1):141161. 
UNEP. 2006. Marine and coastal ecosystems and human well-being: a synthesis report based on the findings of the millennium ecosystem assessment. Nairobi (Kenya): United Nations Environment Programme.

University of Michigan China Data Center. 2007. Population grid data 2000 w/township boundary maps (Shanghai, Jiangsu, Zhejiang, and Anhui). Available from: http://www.cartographic.com/

Wang L, Lyons J, Kanehl P. 2001. Impacts of urbanization on stream habitat and fish across multiple spatial scales. Environmental Management. 28(2):255-266.

Wang X, Wang S, Yan S, Zhang H, Shao T. 2008. Assessing the values of ecosystem services of the Yangtze Delta, China. International Journal of Sustainable Development \& World Ecology. 15(S1):18S-24S.

Wolman H, Galster G, Hanson R, Ratcliffe M, Furdell K, Sarzynski A. 2005. The fundamental challenge in measuring sprawl: which land should be considered? The Professional Geographer. 57(1):94-105.

World Bank. 2004. World development indicators 2004. Washington (DC): World Bank.

World Bank. 2010. Climate risks and adaptation in Asian coastal megacities. Washington (DC): World Bank.

Xie Y. 2009. Zhongguo sheng wu duo yang xing [Biodiversity atlas of China]. Changsha (China): Hunan Education Publishing. Chinese.

Xu S, Chu S, Ju G. 2010. Suzhou dili [Suzhou geography]. Suzhou (China): Guwuxuan Publishing House. Chinese.

Yuan Z, Xu Y, Liu A. 2005. Recent changes of the planting structure of cash crops in China. Review of China Agricultural Science and Technology. 7(5):39-45. Chinese.

Zhao S, Da L, Tang Z, Fang H, Song K, Fang J. 2006. Ecological consequences of rapid urban expansion: Shanghai, China. Frontiers in Ecology and the Environment. 4(7):341-346. 


\section{Tables with captions}

Table 1. Changes in the area of resource sites by regions in 1950, 1979, and 2010 (unit $=1$ $\left.\mathrm{km}^{2}\right)$.

\begin{tabular}{|c|c|c|c|c|c|c|c|c|c|c|c|c|c|c|c|}
\hline \multirow[t]{2}{*}{ Urban regions } & \multicolumn{3}{|c|}{ Forests } & \multicolumn{3}{|c|}{ Wetlands } & \multicolumn{3}{|c|}{ Freshwater sites } & \multicolumn{3}{|c|}{ Cash crop fields } & \multicolumn{3}{|c|}{ Totals } \\
\hline & 1950 & 1979 & 2010 & $\dagger 1950$ & 1979 & 2010 & 1950 & 1979 & 2010 & 1950 & 1979 & 2010 & 1950 & 1979 & 2010 \\
\hline Shanghai & 18 & 17 & 11 & 201 & 320 & 510 & 1,475 & 1,330 & 1,130 & 1,086 & 1,014 & 865 & 2,780 & 2,681 & 2,516 \\
\hline Suzhou & 227 & 218 & 146 & 935 & 850 & 773 & 2,724 & 2,636 & 2,199 & 1,052 & 1,016 & 872 & 4,938 & 4,720 & 3,990 \\
\hline Wuxi-Changzhou & 1,084 & 1,074 & 814 & 1,031 & 888 & 764 & 2,627 & 2,549 & 2,192 & 599 & 582 & 519 & 5,341 & 5,093 & 4,289 \\
\hline Zhenjiang-Yangzhou* & 751 & 758 & 407 & 220 & 185 & 155 & 1,754 & 1,706 & 1,547 & 481 & 468 & 441 & 3,206 & 3,117 & 2,550 \\
\hline Nanjing* & 954 & 952 & 554 & 336 & 288 & 247 & 2,204 & 2,112 & 1,899 & 787 & 766 & 727 & 4,281 & 4,118 & 3,427 \\
\hline Taizhou-Nantong* & 17 & 22 & 1 & 131 & 158 & 191 & 1,000 & 972 & 869 & 1,637 & 1,631 & 1,576 & 2,785 & 2,783 & 2,637 \\
\hline Huzhou & 2,768 & 2,760 & 2,565 & 639 & 513 & 411 & 1,981 & 1,941 & 1,847 & 251 & 234 & 214 & 5,639 & 5,448 & 5,037 \\
\hline Jiaxing & 94 & 86 & 40 & 229 & 173 & 130 & 909 & 884 & 800 & 923 & 914 & 886 & 2,155 & 2,057 & 1,856 \\
\hline Hangzhou-Ningbo* & 3,142 & 3,153 & 2,940 & 272 & 399 & 586 & 1,491 & 1,442 & 1,289 & 693 & 681 & 627 & 5,598 & 5,675 & 5,442 \\
\hline Xuancheng* & 5,955 & 5,957 & 5,493 & 373 & 309 & 256 & 2,024 & 2,032 & 2,006 & 739 & 731 & 712 & 9,091 & 9,029 & 8,467 \\
\hline Totals & 15,010 & 14,997 & 12,971 & 4,370 & 4,083 & 4,023 & 18,189 & 17,604 & 15,778 & 8,248 & 8,037 & 7,439 & 45,817 & 44,721 & 40,211 \\
\hline
\end{tabular}

Note: Each value was calculated based on the number of resource sites within the sample boundaries of each regional-level city (above "urban regions" column). The right-side column "Totals" are summation of the cells of forests, wetlands, freshwater, and cash crop sites for each year.

* Only parts of Yangzhou, Nanjing, Taizhou, Nantong, Hangzhou, Ningbo, and Xuancheng were included for the calculation, since the outer boundary of the defined region does not cover all of these cities' administrative areas. Thus, the size of resource sites in these cities is likely to be underestimated.

† Wetland data in 1950 was not available. Thus, the trend between 1950 and 1979 was linearly extrapolated based on the changes between 1979 and 2010, although this assumption is likely to underestimate the size of wetlands in 1950. 
Table 2. Regression result: Significant factors associated with resource losses.

\begin{tabular}{lrrr}
\hline $\begin{array}{l}\text { Dependent variable: } \\
\text { \% resource loss }\end{array}$ & $\begin{array}{r}\text { Regression } \\
\text { coefficients }\end{array}$ & $\begin{array}{r}\text { Standardized } \\
\text { coefficients }\end{array}$ & $\mathrm{P}>|\mathrm{t}|$ \\
Moran's I & 13.53 & 0.282 & 0.013 \\
Urban spread & 0.025 & 0.286 & 0.001 \\
Soil texture (silt) & 4.67 & 0.219 & 0.006 \\
Population growth & -1.07 & -0.150 & 0.043 \\
\hline
\end{tabular}

Note: Correlation coefficients of each listed variable were analyzed using multiple regression analysis with backward elimination with the percentage variance in resource losses. The four variables were retained at $5 \%$ significance level. Initial independent variables were per $\mathrm{km}^{2}$ lengths of expressways $\left(\mathrm{km} / \mathrm{km}^{2}\right)$, distances to four largest cities $(\mathrm{km})$, number of towns within $50 \mathrm{~km}$ distance from the center of each sampling boundary, density of industrial enterprises, presence of land subsidence, presence of timber or mining sites, average land slopes (degrees), soil groups (clay/silt/sand; above), natural logarithm of total population (2000), row-standardized Moran’s I of urban spread patterns (above), relative increases in urban spread (above), and population growth ratio (total population in 2005 divided by total population in 1997; above). The above regression model is statistically significant, $\mathrm{F}=17.5, \mathrm{~N}=94, \mathrm{R}^{2}=0.35, \mathrm{P}<0.0001$. 


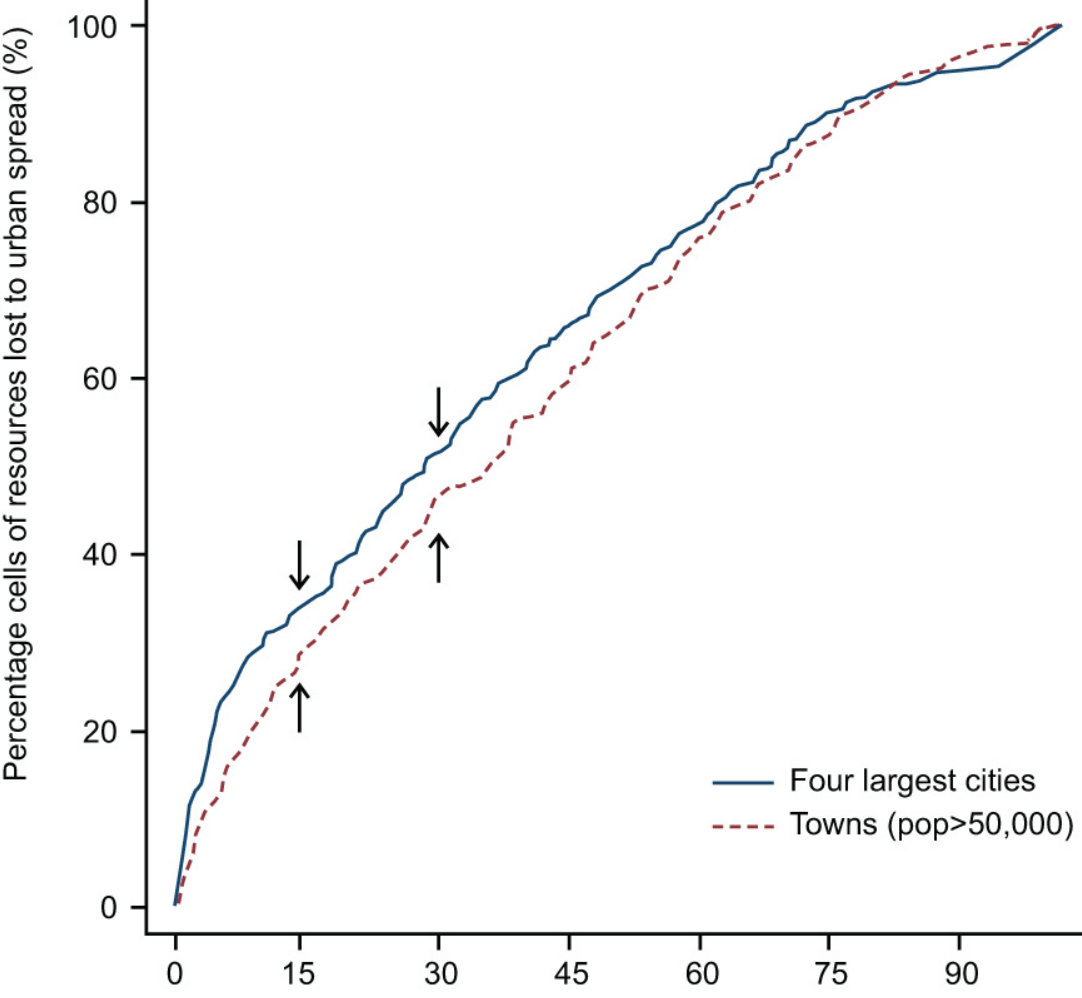


Highly dispersed

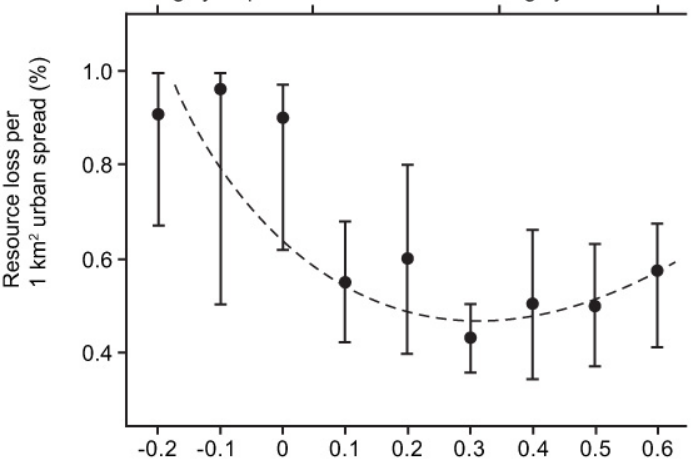

Moran's I cofficients 


\section{Figure captions}

Figure 1. Regional distribution of four types of environmental resources and cumulative resource loss by urban spread between 1950 and 2010.

Note: Coastal lines and water bodies were drawn based on the year of 2010.

Figure 2. Percentage of resource sites lost to urban spread (1950-2010).

Note: Relationship between buffer areas (x-axis) and the extent of resource sites lost to urban spread (y-axis) is compared between 4 largest cities and 230 towns. Buffer area is the percentage of aggregated buffer rings drawn from the centres of cities/towns to the total land surface. Extent of the lost resource sites is based on the percentage of the number of resource loss (red dots) to the total resource sites. Vertical arrows show 15\% buffer area and 30\% buffer area criteria, respectively.

Figure 3. Relationship between resource loss per unit area of urban spread and Moran's I coefficients. 